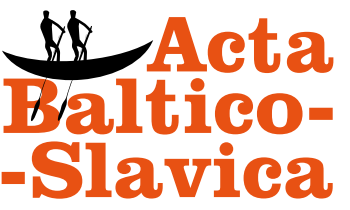

Acta Baltico-Slavica, 39

Warszawa 2015

DOI: $10.11649 /$ abs.2015.009

\title{
Вилия Сакалаускене
}

Институт литовского языка

Вильнюс

\section{Славянизмы в литовских диалектных словарях}

Завершение работы над большим Словарем литовского языка открыло новые возможности для подготовки диалектных словарей, которые позволяют не только зафиксировать областную лексику, но и показать ее систему, выяснить функционирование диалектных слов в различных говорах, показать их развитие и употребление, отметить появление новых лексем.

Как словарь литературного языка, так и словарь диалекта или говора тесно связан с жизнью и разнообразными ее проявлениями (Sakalauskiené, 2006а, c. 222, 2006b, c. 75). Каждый составленный областной словарь важен для истории языка, так как в нем отражено развитие диалектной лексики и морфологии (Sakalauskiené, 2014, c. 141).

Территориально ограниченная лексика развивается вместе с изменяющимися условиями жизни: из употребления уходят многие старые диалектные слова и выражения, которые в литературном языке и других говорах вообще не употребляются либо имеют другое значение, а на их месте появляются совсем новые слова. Те же процессы касаются употребляемых в говорах заимствований, которые также включаются в словари, поскольку несут информацию, важную при исследовании системы языка (необходимую, например, для установления лексических и семантических связей).

Исследование славянизмов в диалектах началось с монографической работы польского лингвиста Яна Отрембского (Otrębski, 1932). Во введении автор указывал на то, что в книге анализируются славянизмы только одного

This is an Open Access article distributed under the terms of the Creative Commons Attribution 3.0 PL License (creativecommons.org/licenses/by/3.0/pl/), which permits redistribution, commercial and non-commercial, provided that the article is properly cited. (c) The Author(s) 2015. 
диалекта (Твярячюса $\left.{ }^{1}\right)$ и одного синхронного среза. Автор подчеркивал, что эта работа отличается от исследования Пранаса Скарджюса (Skardžius, 1931).

Разумеется, большинство славянизмов встречается в тех литовских говорах, которые непосредственно контактировали или контактируют со славянскими языками. Прямые контакты обнаруживаются в южноаукштайтском говоре, который представлен в Словаре диалекта Друскининкай (Drsk Ž, 1988) и в несколько раз большем по объему словаре южной части южноаукштайтских говоров; восточноаукштайтские вильнюсские говоры представлены в трех словарях: в Словаре диалекта Лазунай (LzŽ, 1985), в Словаре говора Девянишки (DvŽ, 2005, 2010) и в Словаре говора Калтаненай (KltŽ, 2008); лексика западноаукштайтских каунасских говоров зафиксирована в четырех словарях: в трехтомном Словаре занавикского говора (ZanŽ, 2003, 2004, 2006), в двухтомном Словаре говора Казлу Pуды (KzRŽ, 2008, 2010), в Словаре деревни Dаукшяй (DkšŽ, 2002) и в Словаре

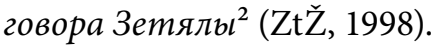

Издан также словарь восточноаукштайтского купишкского говора - Словарь купишкского говора (Кр乙̌, 2007, 2010, 2012, 2013) и словарь восточноаукштайтского ширвинтского говора - Словарь говора Видишкяй (Vdšǩ̆, 2014). Два словаря посвящены жемайтским говорам: Словарь северо-восточных говоров дунининков (DūnŽ, 1976) и Словарь говора Кретинги (KrtnŽ, 2011).

В настоящее время готовятся: Словарь говора Йонишкиса (словарь западноаукштайтского шяуляйского говора), Словарь юрбаркского говора (словарь западноаукштайтского каунасского говора), Словарь северо-западных жемайтов (словарь северножемайтского тельшяйского говора).

Факторы, стимулирующие появление заимствований, всесторонне описывает Вейнрейх, относя к ним: 1) Потребность наименования новых вещей, лиц, мест, понятий. Эта причина считается наиболее универсальной. Заимствования такого типа появляются в связи с тем, что использовать готовое слово экономичнее, чем искать новое наименование; 2) Внутренние языковые факторы. Они характерны для двуязычных ситуаций общения, когда часто употребляемое заимствование носитель языка вспоминает намного быстрее , чем свое исконное слово. Заимствование, таким образом, занимает место родного слова, вытесняя его на периферию, сохраняя при этом его лексическое значение. Этот фактор близок к потребности наименования новой реалии; 3) Необходимость использования синонимов. Считается, что для таких семантических полей, как речь, бытие, сон,

1 В действительности же в работе описаны славянизмы не всего диалекта Твярячюса, а лишь их часть, так как автор ссылался на данные лишь нескольких информантов из деревни Гунтаунинкай (Kardelis, 2003, с. 15, ср. Zinkevičius, 1986).

${ }^{2}$ Говор Зетялы по фонетическим особенностям относится к западноаукштайтским каунасским говорам. 
pост, внешность, постоянно требуются синонимы. Нужный синоним можно найти в другом языке; 4) Социальная значимость языка. По этой причине появляются так называемые ненужные заимствования, обозначающие те реалии, которые можно называть с помощью существующих исконных слов; 5) Психологические факторы. По неосмотрительности говорящего, в речь попадают заимствования, чаще всего возникающие при двуязычном общении (Weinreich, 1974, cc. 57-61).

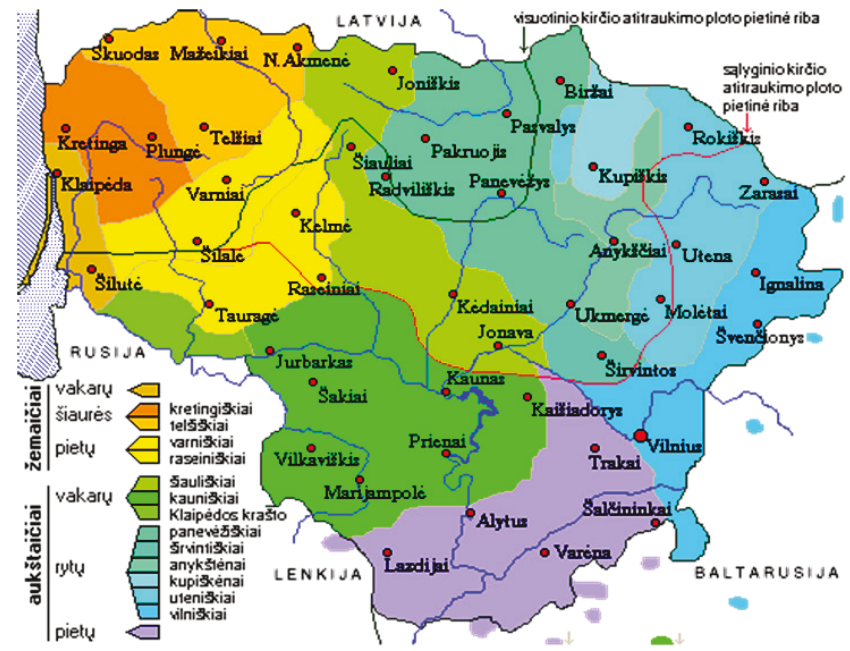

Рис. 1. Диалекты литовского языка (карта из базы Диалектного архива)

Языковые изменения объясняются тем, что заимствования, вошедшие в диалект, в настоящее время приспособлены к соответствующим диалектным нормам. Заимствованная лексика обычно адаптируется фонетически и морфологически. Иногда адаптирование связывается и со словообразованием, а также с семантическим развитием.

Большую часть заимствований составляют славянизмы из белорусского, польского и русского языков. В ряде случаев трудно, а иногда и вообще невозможно определить, из какого славянского языка пришло в говор то или иное слово, потому что в разных славянских языках оно может иметь одно и то же значение, а в некоторых случаях - сходство и в фонетическом плане (Urbutis, 1992, с. 5).

В литовских диалектных словарях славянизмы и другие заимствования выделяются по-разному: в одних словарях после заголовочного слова в скобках используется помета svet. или $s v$. (т. е. заимствование), в других - sl. (т. е. славянизм) или же даются соответствия, например: raštavõnès (бел. pыштава́нне, польск. rusztowanie) 'строительные леса' (DvŽ, 2010, c. 164), stõravotis (польск. starać się, бел. старава́ц̧ия) 'заботиться' (DvŽ, 2010, с. 294), kamizélka (польск. kamizelka) 'жилет' (DvŽ, 2005, с. 240). 
Многие заимствования в настоящее время уже не встречаются в речи старшего поколения носителей говора, но все они фиксируются в диалектных словарях. Например, в них можно найти славянизмы, обозначающие человека, который занимается определенным ремеслом или выполняет какую-либо функцию, в то время как в живом языке эти слова уже не употребляются:

- Beñdorius (бел. бо́ндар, рус. бо́ндаръ) (DvŽ, 2005, с. 59), в литовском литературном языке употребляется kubilius;

- Kamárnykas 'судебный пристав' (ZanŽ, 2003, с. 604), ср. польск. komornik 'urzędnik państwowy powołany do przymusowego ściągania należności od dłużnika na podstawie orzeczeń sądu’3, значение 'землемер', ср. бел. комо́рникб 'землемер' (KltŽ, 2008, c. 97; DrskŽ, 1988, c. 134; DvŽ, 2005, c. 239; KpŽ, 2010, c. 161; KrtnZ̆, 2011, с. 142). П. Скарджюс считал, что это слово происходит из белорусского языка (Skardžius, 1931, c. 94). В. Смочински также выводит происхождение этой лексемы из бел. komórnik (Smoczyński, 2007, c. 251). Высказывается также мнение, что термин komornik 'землемер' является семантическим архаизмом, который был распространен на территории Литвы еще в XIX веке в региональном польском языке (польск. polszczyzna pólnocnokresowa) и через него проник в литовские диалекты (cp. Sawaniewska-Mochowa, 2002, c. 142);

- Kùрс̌ius 'купец; покупатель', ср. польск. kupiec 'ten, kto prowadzi w imieniu własnym przedsiębiorstwo handlowe; kto się trudni handlem; właściciel sklepu', бел. купе́ (ZtŽ, 1998, с. 332; KrtnŽ, 2011, с. 196; KltŽ, 2008, c. 130; DrskZ̆, 1988, c. 176; ZanŽ, 2003, c. 808; KpŽ, 2010, c. 525; Skardžius, 1931, c. 116); значение 'купец' зафиксировано в DvŽ (2005, с. 323); Otrębski (1932, с. 28), 'работодатель' - в KzRŽ (2008, с. 407);

- Rimorius, rỹmorius 'шорник', ср. польск. rymarz 'rzemieślnik trudniący się wyrobem i reperacją przedmiotów ze skóry (z wyjątkiem butów), a zwłaszcza uprzęży końskiej, siodeł; pasów' (ZanŽ, 2004, c. 557; KzRŽ, 2010, c. 176; KpZ̆, 2012, c. 499; DrskZ̆, 1988, c. 305). Данные LKZ̆ (2005) показывают, что это слово широко употребляется в южноаукштайтских, но зафиксировано также в жемайтских и восточноаукштайтских говорах.

Некоторые славянизмы зафиксированы в словарях тех говоров, которые находятся далеко друг от друга, например:

- Smãlius 'человек, занимающийся добычей смолы', ср. польск. smolarz 'człowiek zajmujący się wyrobem albo sprzedażą smoły’, бел. смалá, зафиксировано

${ }^{3}$ Польские слова и их значения приводятся из интернет-версии “Словаря польского языка" В. Дорошевского (ред.), а белорусские - из словаря белорусского языка, составленного И. Носовичем (Носовичъ, 1870). 
в ZanŽ, 2006, с. 114; варианты: smaliõris (ZtŽ, 1998, с. 607) и smaliõrius (DrskŽ, 1988, c. 337);

- Striẽlčius 'стрелец; охотник; лесничий', ср. польск. strzelec, бел. стрэлеи (KrtnŽ, 2011, c. 394; DvŽ, 2010, c. 299; Otrębski, 1932, с. 52), вариант strielčis 'стрелец' (ZtŽ, 1998, с. 632), значение 'охотник; лесничий' (ZanŽ, 2006, с. 196; Крц̌, 2012, с. 876), только 'охотник' (DrskŽ, 1988, с. 352);

- Šaltỹšius 'староста' (лит. 'kaimo seniūnas'), ср. польск. sołtys, устарелое и диал. szołtys, sołtes, szałtys, szołtys(z) 'osoba kierująca pracą wiejskich władz samorządowych najniższego szczebla' (ZtŽ, 1998, c. 652; ZanŽ, 2006, c. 245); польское слово происходит от немецкого Schultheiss (Brückner, 1957, c. 507; Boryś, 2006, c. 567);

- Urëdas 'надсмотрщик', ср. бел. урадъ (DvŽ, 2010, c. 452; ZanŽ, 2006, c. 531; KzRZ̆, 2010, с. 435; KpŽ, 2013, с. 522). На происхождение этого слова от бел. урадъ указывает старобелорусск. urjad (FrnW, 1965, c. 1170; Smoczyński, 2007, c. 706). П. Скарджюс отмечает urédas и urédnykas (Skardžius, 1931, с. 229). Слово употреблялось в памятниках древней письменности, но зафиксировано и в диалектных словарях.

Приведенные примеры показывают интересную закономерность, когда один и тот же славянизм фиксируется на территории двух соседних говоров, которые разделены третьим, граничащим с первым и вторым. Об этой закономерности свидетельствуют славянизмы, включенные в словари западноаукштайтского каунасского говора. Говор этот является одним из центральных диалектов, для него характерно практически полное отсутствие контактов с другими языками. Однако, как известно, заимствование слов может происходить и вне ситуации языкового контакта, так как слова приходят вместе с заимствованием объектов культуры и цивилизации, а для этого прямые контакты не нужны (Karaliūnas, 1997, с. 356).

Исследованиями потверждено, что потребность в наименовании новых понятий является основной причиной заимствования слов. Принято считать, что именно этим определяется и тот факт, что большинство заимствований составляют имена существительные. Расхождение значений исконного (старого) и чужого слова может быть причиной появления синонимического заимствования и в одноязычном обществе: замечено, что заимствования называют, как правило, новые синонимические понятия (Stundžia, 1978, с. 138-139).

Иногда у того или иного человека выделяется какая-либо черта (характера или внешности), и таким образом создается прецедент к возникновению прозвища. Чаще всего такие названия лиц подчеркивают негативные, очень заметные особенности человека (cp. Rutkowska \& Sawaniewska-Mochowa, 2012, c. 124). Наряду с исконными словами, в словарях зафиксированы и славянизмы, например: 
- Balamūtas 'безнравственный человек, баловник', ср. с польск. bałamut 'człowiek niepoważny, szerzący zamęt', бел. баламуm (KltŽ, 2008, с. 17), 'кто болтает пустяки' (KrtnŽ, 2011, с. 38; ZanŽ, 2003, c. 102; KpŽ, 2007, c. 138);

- Laidõkas 'негодник, распутник; пьяница, лентяй', ср. с польск. łajdak 'człowiek niegodziwy, godny potępienia i pogardy; łotr, szelma', бел. лайдáк (KltŽ, 2008, c. 134; DvŽ, 2005, c. 334; DrskZ̆, 1988, c. 182; KzRZ̆, 2008, c. 417; ZanŽ, 2004, c. 9; KrtnŽ, 2011, c. 203);

- Lakudrà 'опустившийся человек, пьяница, бродяга', ср. с польск. łachudra 'człowiek nędzny, godny pogardy; drań, szubrawiec' (KzRŽ, 2010, c. 426; ZanŽ, 2004 , с. 22; KpZ̆, 2010, с. 582), значение 'неспокойный человек, тот, кто бегает, шатается' (KrtnŽ, 2011, с. 205), вариант lakūdra (KltŽ, 2008, c. 136);

- Lapsardõkas 'неряха, бродяга', ср. с польск. łapserdak'1. człowiek źle, nędznie ubrany, obdartus, obszarpaniec; 2. gałgan, nicpoń, łobuz' (ZanŽ, 2004, c. 27; KzRŽ, 2008, с. 428). Это слово в польском языке имеет два значения. Как показывает пример, двойное значение зафиксировано в словарях западноаукштайтских говоров. В словаре восточноаукштайтских говоров представлено переносное значение слова, обозначающее одежду - 'порванный пиджак, плащь' (КрŽ, 2010, с. 592);

- Lãtras 'бродяга, пьяница', ср. с польск. łotr 'człowiek popełniający czyny haniebne; łajdak, niegodziwiec', слово встречается в западно- и восточноаукштайтских и северножемайтских говорах (ZanŽ, 2004, с. 29; KzRZ̆, 2008, с. 430; KpZ̆, 2010, c. 596; KrtnZ̆, 2011, с. 207); происхождение этого слова в польском языке - из немецкого Lotter (Boryś, 2006, c. 302);

- Razbáinykas 'грабитель, разбойник', ср. с польск. rozbójnik 'ten, kto uprawia rozbój; napada na kogo; bandyta, zbój, opryszek', бел. разбойнік (KltŽ, 2008, c. 245; DrskŽ, 1988, c. 300; ZtŽ, 1998, c. 538; ZanŽ, 2004, c. 535; Kp̌̆, 2012, c. 463), вариант razbáininkas зафиксирован в $\operatorname{KrtnZ̆~(2011,~с.~338);~}$

- Špiegas 'шпион', ср. с польск. szpieg 'agent obcego wywiadu, osoba gromadząca i przekazująca obcemu państwu wiadomości, dokumenty stanowiące tajemnicę państwową lub wojskową̧ встречается только в аукштайтских говорах (KltŽ, 2008, c. 325; DvŽ, 2010, c. 368; ZtŽ, 1998, c. 672; ZanŽ, 2006, c. 330); происхождение слова из польского языка подтверждает П. Скарджюс и др. (Skardžius, 1931, c. 217; FrnW, 1965, c. 1024);

- Славянизм ultõjus 'лентяй', ср. с польск. hultaj 'człowiek prowadzący hulaszcze, próżniacze życie; nicpoń, łobuz, szelma', бел. гульта́ú 'лентяй, лодарь, бездельник' (FrnW, 1965, с. 1162) употребляется в южно- и восточноаукштайтских

${ }^{4}$ В польском языке это слово считается устаревшим, но в литовском южноаукштайтском говоре оно до сих пор употребляется очень часто. 
говорах (DvŽ, 2010, c. 446; DrskŽ, 1988, c. 428; KltŽ, 2008, с. 368), вариант ultõjis (ZtŽ, 1998, c. 723).

Зафиксированные в словарях славянизмы со значением различных предметов быта показывают, что многие из них употребляются только в некоторых соседних говорах, например, в южноаукштайтских: apcūgos 'клещи' (KltŽ, 2008, с. 6), apceñgos (ZtŽ, 1998, c. 55), ср. с польск. obcęgi, бел. oбиуzi; apsõcas 'каблук', польск. obcas, бел. абса́и (абцас) (Otrębski, 1932, с. 6), слово зафиксировано также в восточноаукштайтском говоре (KltŽ, 2008, с. 7); caberkas, ceberas 'деревянная посуда с ушами, чан' (KltŽ, 2008, с. 30), ср. с. польск. ceber 'duże okrągłe naczynie z klepek, zwykle o dwóch uchach z otworami'; cébras (DrskŽ, 1988, c. 48; DvŽ, 2005, c. 83); čepelà 'чапельник, сковородник', ср. польск. сzepioła (ZtŽ, 1998, c. 113); ušetkas, cp. бел. ушаток, русск. ушат 'широкая деревянная посуда с двумя ушами, чан' (KltŽ, 2008, с. 371; ZtŽ, 1998, с. 725; DvŽ, 2010, с. 452), вариант ušietkas (KrtnZ̆, 2011, c. 466). В других говорах эти лексемы неизвестны.

Заимствования адаптируются к литовской лексике, чаще всего подчиняясь общим законам диалектной фонетики и грамматики. Одни лексемы звучат подобно славянским словам, другие опознаются труднее. Значения одних слов совпадают со значениями в языке-источнике, другие модифицируются. Фонетические и морфологические особенности приспосабливаются к системе говоров (Leskauskaitè, 2006, с. 397).

Выявляется и другая тенденция. Случается, что в говоре наряду с заимствованиями употребляются и литовские соответствия. Представители говоров считают это особенностью простой речи, поэтому стараются заимствования заменить исконными словами. Например, nõvalačka (KltŽ, 2008, c. 191), cp. pyc. наволочка, польск. nawleczka. В этом же словаре можно найти и лит. üžvelkalas; bagótas 'богатый' (DvŽ, 2005, c. 43), ср. бел. богámbl, польск. bogaty и лит. turtingas 'богатый' (DvŽ, 2010, с. 439); kaimýnas 'сосед' (DvŽ, 2005, c. 230) и susiedas 'сосед' (DvŽ, 2010, c. 313), cp. бел. сусе́д, рус. сосе́d; ronà 'рана' (DvŽ, 2010, c. 195), ср. бел. ра́на, польск. гапа и лит. žaizda 'рана' (DvŽ, 2010, c. 553).

Лексика представляет собой весьма специфическую область языка. Она открыта для различных влияний. Из всех уровней языка именно лексика является самой чувствительной и легче всего подвергается изменениям. На нее влияют различные интралингвистические и экстралингвистические факторы. Заимствование слов не обусловлено природой самого языка. Его интенсивность во многом зависит от внешних условий существования языка (или диалекта). Кроме того, заимствованиями часто заполняются пробелы (незанятые клетки) в лексической системе.

5 В польском языке это слово в данном значении уже не употребляется, оно известно только в польских говорах Литвы и переселенцам из Вильнюсского округа (Kurzowa, 1993, с. 344). 


\section{ВЫВОДЫ}

1. Системная организация диалектных словарей позволяет изучать разные слои лексики, в том числе и славянизмы, помогает сравнивать их употребление в разных диалектах. Лексическая система словаря показывает функцирование заимствований в диалекте, их соотношение с исконными словами.

2. При изучении славянизмов в диалектах необходимо учитывать особенности их употребления как в отдельных слоях лексики, так и в отдельных словарях. Исследование зафиксированных славянизмов дает огромный материал для освещения их истории, помогает точнее определить, как и почему они распространялись.

3. Славянизмы не вытесняют исконную лексику, а зачастую функционируют наряду с ней в качестве синонимов.

4. Сравнение «литовских» славянизмов с соответствующими словами в польском языке показывает, что многие из них уже не употребляются в современном польском языке, но наличие таких слов в литовских диалектных словарях свидетельствует о том, что в речи старшего поколения носителей говоров многие славянизмы употребляются до сих пор. Значение некоторых славянизмов в говоре может сужаться или, наоборот, расширяться.

\section{Сокращенные обозначения использованных словарей}

DkšŽ — Labutis, V. (2002). Daukšiu krašto žodynas, Vilnius: Alma littera.

DrskZ̆ $\quad$ - Naktinienè, G., Paulauskienè, A., Vitkauskas, V. (1988). Druskininkų tarmès žodynas. Vilnius: Mokslas.

DūnŽ — - Vitkauskas, V. (1976). Šiaurès rytų dūnininkų šnektų žodynas. Vilnius: Mokslas.

DvŽ I - Grumadienè, L., Mikulenienè, D., Morkūnas, K., Vidugiris A. (2005). Dieveniškiu šnektos žodynas. Vilnius: Lietuvių kalbos institutas.

DvŽ II - Mikulènienè, D., Morkūnas, K., Vidugiris A. (2010). Dieveniškių šnektos žodynas. Vilnius: Lietuvių kalbos institutas.

FrnW I, II - Fraenkel, E. (1962-1965). Litauisches etymologisches Wörterbuch. Heidelberg: Carl Winter Universitätsverlag, Göttingen: Vandenhoeck \& Ruprecht.

KltŽ - Vilutytė, A. (2008). Kaltanènų šnektos žodynas. Vilnius: Lietuvių kalbos institutas.

KpŽ I, II, III, IV - Vosylytė, K. (2007, 2010, 2012, 2013). Kupiškènų žodynas. Vilnius: Lietuvių kalbos institutas.

KrtnŽ - Aleksandravičius, J. (2011). Kretingos tarmès žodynas. Vilnius: Lietuvių kalbos institutas. 
KzRŽ I, II - Pupkis, A. (2008, 2010). Kazlų Rūdos šnektos žodynas, Vilnius: Lietuvių kalbos institutas.

LKŽ J. Paulauskas, R. Petrokiené, V. Vitkauskas, J. Zabarskaitè, 2005, Vilnius: Lietuvių kalbos institutas, elektroninis leidimas, $w w w . l k z . l t$

LzŽ - Petrauskas, J., Vidugiris, A. (1985). Lazūnų tarmès žodynas. Vilnius: Mokslas.

VdškŽ - Markevičienè, Ž., Markevičius, A. (2014). Vidiškių šnektos žodynas. Vilnius: Lietuvos edukologijos universitetas, Lietuvių kalbos institutas.

ZanŽ I - (2003). Zanavyku šnektos žodynas. Vyr. red. A. Pupkis. Vilnius: Mokslo ir enciklopedijų leidybos institutas.

ZanŽ II - (2004). Zanavyku šnektos žodynas. Vyr. red. V. Sakalauskienè. Vilnius: Mokslo ir enciklopedijų leidybos institutas.

ZanŽ III - (2006). Zanavykų šnektos žodynas. Vyr. red. V. Sakalauskienè. Vilnius: Mokslo ir enciklopedijų leidybos institutas.

ZtŽ - Vidugiris, A. (1998). Zietelos šnektos žodynas. Vilnius: Mokslo ir enciklopediju leidybos institutas.

\section{Bibliography}

Aleksandravičius, J. (2011). Kretingos tarmès žodynas [KrtnŽ]. Vilnius: Lietuvių kalbos institutas. Boryś, W. (2006). Słownik etymologiczny języka polskiego. Kraków: Wydawnictwo Literackie. Brückner, A. (1957). Słownik etymologiczny języka polskiego. Kraków: Wiedza Powszechna.

Doroszewski, W. (Ed.). Słownik języka polskiego. Wydawnictwo Naukowe PWN. Retrieved from http://doroszewski.pwn.pl/

Fraenkel, E. (1962). Litauisches etymologisches Wörterbuch [FrnW] (Vol. 1). Heidelberg: Carl Winter Universitätsverlag.

Fraenkel, E. (1965). Litauisches etymologisches Wörterbuch [FrnW] (Vol. 2). Heidelberg: Carl Winter Universitätsverlag.

Grumadienė, L., Mikulènienė, D., Morkūnas, K., \& Vidugiris A. (2005). Dieveniškiu šnektos žodynas [DvŽ] (Vol. 1). Vilnius: Lietuvių kalbos institutas.

Karaliūnas, S. (1997). Kalba ir visuomenè: Psichologiniai ir komunikaciniai kalbos vartojimo bruožai. Vilnius: Lietuvių kalbos institutas.

Kardelis, V. (2003). Rytų aukštaičių šnektų slavizmų fonologijos bruožai. Vilnius: Vilniaus universiteto leidykla.

Kurzowa, Z. (1993). Język polski Wileńszczyzny i kresów pólnocno-wschodnich XVI-XX w. Warszawa, Kraków: Wydawnictwo Naukowe PWN.

Labutis, V. (2002). Daukšių krašto žodynas [DkšŽ]. Vilnius: Alma littera.

Leskauskaitè, A. (2006). Pietvakarinio Lietuvos paribio šnektos ir slavų kalbos. Acta Baltico-Slavica, 30, 391-402. 
Markevičienè, Ž., \& Markevičius, A. (2014). Vidiškių šnektos žodynas [VdškŽZ]. Vilnius: Lietuvos edukologijos universitetas, Lietuvių kalbos institutas.

Mikulènienè, D., Morkūnas, K., \& Vidugiris, A. (2010). Dieveniškių šnektos žodynas [DvŽ] (Vol. 2). Vilnius: Lietuvių kalbos institutas.

Naktinienè, G., Paulauskas, J., Petrokienè, R., Vitkauskas, V., \& Zabarskaitė, J. (2005). Lietuviu kalbos žodynas 1-20 [LKŽ ]. Vilnius: Lietuvių kalbos institutas. Retrieved from www.lkz.lt

Naktinienè, G., Paulauskienè, A., \& Vitkauskas, V. (1988). Druskininkų tarmés žodynas [DrskŽ]. Vilnius: Mokslas.

Otrębski, J. (1932). Wschodniolitewskie narzecze twereckie (Pt. 3: Zapożyczenia słowiańskie). Kraków: Drukarnia Uniwersytetu Jagiellońskiego pod zarządem J. Filipowskiego.

Petrauskas, J., \& Vidugiris, A. (1985). Lazūnų tarmès žodynas [LzŽ]. Vilnius: Mokslas.

Pupkis, A. (2008). Kazlų Rūdos šnektos žodynas [KzRŽ] (Vol. 1). Vilnius: Lietuvių kalbos institutas.

Pupkis, A. (2010). Kazlų Rūdos šnektos žodynas [KzRŽ] (Vol. 2) Vilnius: Lietuvių kalbos institutas.

Pupkis, A. (Ed.). (2003). Zanavykų šnektos žodynas [ZanŽ] (Vol. 1). Vilnius: Mokslo ir enciklopedijų leidybos institutas.

Rutkowska, K., \& Sawaniewska-Mochowa, Z. (2012). Zapożyczenia litewskie dotyczące człowieka w gwarach polskich na Litwie: Aspekt semantyczny i etnolingwistyczny. Baltistica, (8 Priedas), 123-141.

Sakalauskienė, V. (2006a). Leksiniai slavizmai pietinių vakarų aukštaičių šiaurinèje šnektoje. Acta Baltico-Slavica, 30, 221-231.

Sakalauskienė, V. (2006b). Tarmių ir kalbų sąveika: vakarų aukštaičių kauniškių slavizmai. Prace Battystyczne, 3, 75-81.

Sakalauskienè, V. (2014). Lietuvių tarminių žodynų tipai ir jų rengimo principai. Leksikografija ir leksikologija, (4), 141-157.

Sakalauskienè, V. (Ed.). (2004). Zanavykų šnektos žodynas [ZanŽ] (Vol. 2). Vilnius: Mokslo ir enciklopedijų leidybos institutas.

Sakalauskienè, V. (Ed.). (2006). Zanavykų šnektos žodynas [ZanŽ] (Vol. 3). Vilnius: Mokslo ir enciklopedijų leidybos institutas.

Sawaniewska-Mochowa, Z. (2002). Ze studiów nad socjolektem drobnej szlachty kowieńskiej XIX wieku: Na podstawie słowników przekładowych Antoniego Juszkiewicza. Bydgoszcz: Wydawn. Akad. Bydgoskiej im. Kazimierza Wielkiego.

Skardžius, P. (1931). Die slavischen Lehnwörter im Altlitauischen. Kaunas: Spindulys.

Smoczyński, W. (2007). Słownik etymologiczny jezzyka litewskiego. Wilno: Uniwersytet Wileński.

Stundžia, B. (1978). Kelios pastabos apie slavizmų funkcionavimą tarminejje leksikoje. Kalbotyra, 32(1), 138-139.

Urbutis, V. (1992). Senosios lietuvių kalbos slavizmai. Baltistica, 27(1), 4-14.

Vidugiris, A. (1998). Zietelos šnektos žodynas [ZtŽ]. Vilnius: Mokslo ir enciklopedijų leidybos institutas. 
Vilutytė, A. (2008). Kaltanėnų šnektos žodynas [KltŽ]. Vilnius: Lietuvių kalbos institutas. Vitkauskas, V. (1976). Šiaurès rytų dūnininkų šnektų žodynas [DūnŽ]. Vilnius: Mokslas. Vosylytė, K. (2007). Kupiškenų žodynas [KpŽ] (Vol. 1). Vilnius: Lietuvių kalbos institutas. Vosylytė, K. (2010). Kupiškènų žodynas [KpŽ] (Vol. 2). Vilnius: Lietuvių kalbos institutas. Vosylytė, K. (2012). Kupiškènų žodynas [KpŽ] (Vol. 3). Vilnius: Lietuvių kalbos institutas. Vosylytė, K. (2013). Kupiškènų žodynas [KpŽ] (Vol. 4). Vilnius: Lietuvių kalbos institutas. Weinreich, U. (1974). Languages in contact: Findings and problems. The Hague: Mouton. Zinkevičius, Z. (1986). Tverečiaus šnektos slavizmai prieš 60 metų ir dabar. Baltistica, 22(2), 8-12. Носовичъ, И. И. (Сотр.). (1870). Словарь бълорусскаго нарбчія. Санктпетербургъ: Типографія Императорской Академіи Наукъ.

\section{Bibliography (Transliteration)}

Aleksandravičius, J. (2011). Kretingos tarmès žodynas [KrtnŽ]. Vilnius: Lietuvių kalbos institutas. Boryś, W. (2006). Słownik etymologiczny języka polskiego. Kraków: Wydawnictwo Literackie. Brückner, A. (1957). Słownik etymologiczny języka polskiego. Kraków: Wiedza Powszechna.

Doroszewski, W. (Ed.). Słownik języka polskiego. Wydawnictwo Naukowe PWN. Retrieved from http://doroszewski.pwn.pl/

Fraenkel, E. (1962). Litauisches etymologisches Wörterbuch [FrnW] (Vol. 1). Heidelberg: Carl Winter Universitätsverlag.

Fraenkel, E. (1965). Litauisches etymologisches Wörterbuch [FrnW] (Vol. 2). Heidelberg: Carl Winter Universitätsverlag.

Grumadienė, L., Mikulėnienè, D., Morkūnas, K., \& Vidugiris A. (2005). Dieveniškių šnektos žodynas [DvŽ] (Vol. 1). Vilnius: Lietuvių kalbos institutas.

Karaliūnas, S. (1997). Kalba ir visuomenè: Psichologiniai ir komunikaciniai kalbos vartojimo bruožai. Vilnius: Lietuvių kalbos institutas.

Kardelis, V. (2003). Rytu aukštaičiu šnektų slavizmų fonologijos bruožai. Vilnius: Vilniaus universiteto leidykla.

Kurzowa, Z. (1993). Język polski Wileńszczyzny i kresów pólnocno-wschodnich XVI-XX w. Warszawa, Kraków: Wydawnictwo Naukowe PWN.

Labutis, V. (2002). Daukšių krašto žodynas [DkšŽ]. Vilnius: Alma littera.

Leskauskaite, A. (2006). Pietvakarinio Lietuvos paribio šnektos ir slavų kalbos. Acta Baltico-Slavica, 30, 391-402.

Markevičienè, Ž., \& Markevičius, A. (2014). Vidiškių šnektos žodynas [VdškŽ]. Vilnius: Lietuvos edukologijos universitetas, Lietuvių kalbos institutas.

Mikulėnienè, D., Morkūnas, K., \& Vidugiris, A. (2010). Dieveniškių šnektos žodynas [DvŽ] (Vol. 2). Vilnius: Lietuvių kalbos institutas. 
Naktinienè, G., Paulauskas, J., Petrokienė, R., Vitkauskas, V., \& Zabarskaitė, J. (2005). Lietuviu kalbos žodynas 1-20 [LKŽ ]. Vilnius: Lietuvių kalbos institutas. Retrieved from www.lkz.lt

Naktinienè, G., Paulauskienè, A., \& Vitkauskas, V. (1988). Druskininkų tarmés žodynas [DrskŽ]. Vilnius: Mokslas.

Nosovich, I. I. (Comp.). (1870). Slovar' bĕlorusskago narĕchīia. Sanktpeterburg: Tipografïia Imperatorskoĭ Akademīi Nauk.

Otrębski, J. (1932). Wschodniolitewskie narzecze twereckie (Pt. 3: Zapożyczenia słowiańskie). Kraków: Drukarnia Uniwersytetu Jagiellońskiego pod zarządem J. Filipowskiego.

Petrauskas, J., \& Vidugiris, A. (1985). Lazūnų tarmès žodynas [LzŽ]. Vilnius: Mokslas.

Pupkis, A. (2008). Kazlų Rūdos šnektos žodynas [KzRŽ] (Vol. 1). Vilnius: Lietuvių kalbos institutas.

Pupkis, A. (2010). Kazlų Rūdos šnektos žodynas [KzRŽ] (Vol. 2) Vilnius: Lietuvių kalbos institutas.

Pupkis, A. (Ed.). (2003). Zanavykų šnektos žodynas [ZanŽ] (Vol. 1). Vilnius: Mokslo ir enciklopedijų leidybos institutas.

Rutkowska, K., \& Sawaniewska-Mochowa, Z. (2012). Zapożyczenia litewskie dotyczące człowieka w gwarach polskich na Litwie: Aspekt semantyczny i etnolingwistyczny. Baltistica, (8 Priedas), 123-141.

Sakalauskienè, V. (2006a). Leksiniai slavizmai pietinių vakarų aukštaičių šiaurinèje šnektoje. Acta Baltico-Slavica, 30, 221-231.

Sakalauskienè, V. (2006b). Tarmių ir kalbų sąveika: vakarų aukštaičių kauniškių slavizmai. Prace Bałtystyczne, 3, 75-81.

Sakalauskienè, V. (2014). Lietuvių tarminių žodynų tipai ir jų rengimo principai. Leksikografija ir leksikologija, (4), 141-157.

Sakalauskienè, V. (Ed.). (2004). Zanavykų šnektos žodynas [ZanŽ] (Vol. 2). Vilnius: Mokslo ir enciklopedijų leidybos institutas.

Sakalauskienè, V. (Ed.). (2006). Zanavykų šnektos žodynas [ZanŽ] (Vol. 3). Vilnius: Mokslo ir enciklopedijų leidybos institutas.

Sawaniewska-Mochowa, Z. (2002). Ze studiów nad socjolektem drobnej szlachty kowieńskiej XIX wieku: Na podstawie słowników przekładowych Antoniego Juszkiewicza. Bydgoszcz: Wydawn. Akad. Bydgoskiej im. Kazimierza Wielkiego.

Skardžius, P. (1931). Die slavischen Lehnwörter im Altlitauischen. Kaunas: Spindulys.

Smoczyński, W. (2007). Słownik etymologiczny języka litewskiego. Wilno: Uniwersytet Wileński.

Stundžia, B. (1978). Kelios pastabos apie slavizmų funkcionavimą tarminëje leksikoje. Kalbotyra, 32(1), 138-139.

Urbutis, V. (1992). Senosios lietuvių kalbos slavizmai. Baltistica, 27(1), 4-14.

Vidugiris, A. (1998). Zietelos šnektos žodynas [ZtŽ]. Vilnius: Mokslo ir enciklopedijų leidybos institutas.

Vilutytè, A. (2008). Kaltanènų šnektos žodynas [KltŽ]. Vilnius: Lietuvių kalbos institutas.

Vitkauskas, V. (1976). Šiaurès rytų dūnininkų šnektų žodynas [DūnŽ]. Vilnius: Mokslas. 
Vosylytė, K. (2007). Kupiškènų žodynas [KpŽ] (Vol. 1). Vilnius: Lietuvių kalbos institutas. Vosylytė, K. (2010). Kupiškènų žodynas [KpŽ] (Vol. 2). Vilnius: Lietuvių kalbos institutas. Vosylytė, K. (2012). Kupiškènų žodynas [KpŽ] (Vol. 3). Vilnius: Lietuvių kalbos institutas. Vosylytė, K. (2013). Kupiškènų žodynas [KpŽ] (Vol. 4). Vilnius: Lietuvių kalbos institutas. Weinreich, U. (1974). Languages in contact: Findings and problems. The Hague: Mouton. Zinkevičius, Z. (1986). Tverečiaus šnektos slavizmai prieš 60 metų ir dabar. Baltistica, 22(2), 8-12.

\section{Славянизмы в литовских диалектных словарях}

\section{Резюме}

В статье рассматриваются литовские диалектные словари, охватывающие словарный материал живой речи либо слова из письменных диалектных источников. На данный момент опубликовано 10 словарей литовских диалектов и ведется работа над 5 новыми словарями.

Изменения в составе диалектной лексики отражают изменения в повседневной жизни ее носителей. Многие старые названия уходят как из литературного языка, так и из диалектов. Некоторые слова сохраняются, но изменяется их значение. Те же процессы охватывают и заимствования в диалектах. Используемое в рассматриваемых словарях лексикографическое описание позволяет отслеживать дистрибуцию заимствований в диалектах в сопоставлении с единицами общенационального литературного языка.

Наиболее обширной группой лексических заимствований являются славянизмы, используемые в диалектах, непосредственно соприкасавшихся с одним из славянских языков: польским, белорусским или русским. В рассматриваемых нами словарях использовались различные методы обозначения славянизмов. В одном из этих словарей в скобках приводится сокращенное название языка, из которого происходит данная лексическая единица; в других же лишь в общих чертах отмечается, что у слова славянское происхождение, и иногда приводятся слова, являющиеся источником заимствования.

В статье описываются некоторые славянизмы, собранные в 10 литовских диалектных словарях. Одной из рассматриваемых в статье словарных групп являются названия профессий: kamarnykas, ср. польское komornik (DrskŽ 134, DvŽ I 239, KltŽ 97, KpŽ II 161, KrtnŽ 142, ZanŽ I 604); kuрс̌ius, ср. польское kupiec, беларусское купеи, (DrskŽ 176, DvŽ I 323, KltŽ 130, KpŽ II 525, KrtnŽ 196, KzRŽ I 407, ZanŽ I 808, ZtŽ 332); strielčius, cp. польское strzelec, беларусское стрэлеи (DrskŽ 352, DvŽ II 299, KpŽ III 876, KrtnŽ 394, ZanŽ III 196); rimorius, ср. польское rymarz (DrskŽ 305, KpŽ III 499, KzRŽ II 176, ZanŽ II 557). 
Состав диалектной лексики формируется различными языковыми и внеязыковыми факторами. Интенсивность диалектных заимствований обуславливается обстоятельствами, внешними по отношению к языку или диалекту, а пробелы, которые могут заполнить заимствования, обнаруживаются лишь в некоторых тематических областях диалектной лексики. Анализ славянизмов, направленный на определение происхождения и причины заимствования иноязычных названий, а также динамики их распространения в литовских диалектах, является частью более широкой проблематики исследований истории литовских диалектов.

Ключевые слова: лексика; диалектный словарь; диалект; заимствование; славянизм

\section{Slawizmy w litewskich słownikach gwarowych}

\section{Streszczenie}

Przedmiotem analizy są litewskie słowniki gwarowe, rejestrujące słownictwo z żywej mowy lub z zapisów w źródłach dialektologicznych. Język litewski doczekał się dotychczas dziesięciu takich słowników, kolejnych pięć jest w opracowaniu.

Zmiany w zasobie słownictwa dialektalnego są pochodną przemian zachodzących w życiu codziennym użytkowników gwar. Wiele starych nazw wycofuje się zarówno z języka literackiego, jak i z dialektów. Niektóre wyrazy zachowują żywotność, ale zmieniają znaczenia. Wskazanym procesom ulegają także zapożyczenia w leksyce gwarowej. Opis leksykograficzny zastosowany w badanych słownikach pozwala śledzić zakres dystrybucji słownictwa zapożyczonego w gwarach w relacji do jednostek języka literackiego.

Najliczniejszą grupę zapożyczeń leksykalnych stanowią slawizmy używane w tych gwarach litewskich, które zetknęły się bezpośrednio z którymś z języków słowiańskich polskim, białoruskim czy rosyjskim. W badanych słownikach zastosowano różne metody kwalifikowania slawizmów. Jedno ze źródeł podaje w nawiasie skrót nazwy języka, z którego przejęta została dana jednostka, inne słowniki sygnalizują tylko ogólnie, że słowo jest pochodzenia słowiańskiego, czasami przywoływane są także wyrazy, które stanowią podstawę zapożyczeń.

$\mathrm{W}$ artykule poddano analizie wybrane slawizmy wyekscerpowane $\mathrm{z}$ dziesięciu słowników gwarowych. Jedną z opisywanych grup znaczeniowych stanowią określania wykonawców zawodów: kamarnykas, por. polskie komornik (DrskŽ 134, DvŽ I 239, KltŽ 97, KpŽ II 161, KrtnŽ 142, ZanŽ I 604); kupčius, por. polskie kupiec, białoruskie 
кyneu (DrskŽ 176, DvŽ I 323, KltŽ 130, KpŽ II 525, KrtnŽ 196, KzRŽ I 407, ZanŽ I 808, ZtŽ 332); strielčius, por. polskie strzelec, białoruskie стрэлеu (DrskŽ 352, DvŽ II 299, KpŽ III 876, KrtnŽ 394, ZanŽ III 196); rimorius, por. polskie rymarz (DrskŽ 305, KpŽ III 499, KzRŽ II 176, ZanŽ II 557).

Zasób leksyki dialektalnej kształtowały różne czynniki językowe i pozajęzykowe. Intensywność zapożyczeń leksykalnych zależy od uwarunkowań zewnętrznych względem języka czy dialektu, a luki, które mogą wypełnić zapożyczenia, występują tylko w niektórych obszarach tematycznych słownictwa gwarowego. Analiza slawizmów ukierunkowana na ustalanie genezy i powodów zapożyczania obcych nazw oraz dynamiki ich rozprzestrzeniania się na gruncie litewskim wpisuje się w szerszą problematykę studiów nad historią dialektów litewskich.

Słowa kluczowe: leksyka; słownik gwarowy; gwara; zapożyczenie; slawizm

\title{
Slavisms in Lithuanian Dialect Dictionaries
}

\begin{abstract}
This arcticle discusses dialect dictionaries where words are recorded either from living language or from other, written sources of dialect. Up to now, ten Lithuanian dialect dictioniaries have been published and five are being compiled. Dialect changes along with our everyday life. A lot of words from the old dialect are being forgotten. Those words are no longer being used in the common language as well as in other dialects. In addition, some words gain new meanings. The same processes apply to loanwords which are used in dialects and are included in dialect dictionaries. The lexical system of a dialect dictionary shows the functioning of loanwords and their relationship with the words of the common language.

The majority of Lithuanian loanwords are Slavisms, used in those dialects which have had a direct contact with Slavic languages, such as Polish, Belarusian or Russian. Slavisms and loanwords from other languages are marked variously in different dictionaries. In one of them, shortened language names are written in parentheses after the entry, which indicates that it is a word of foreign origin. Other dictionaries simply indicate Slavisms or additionally present the foreign equivalent from which they originate.

A number of Slavisms from the dictionaries is analysed in the article. This examplary group are occupation names: kamarnykas ("debt collector"), cf. Polish komornik (DrskŽ 134, DvŽ I 239, KltŽ 97, KpŽ II 161, KrtnŽ 142, ZanŽ I 604); kupčius ("merchant”), cf. Polish kupiec, Belarusian кyneu, (DrskŽ 176, DvŽ I 323, KltŽ 130,
\end{abstract}


KpŽ II 525, KrtnŽ 196, KzRŽ I 407, ZanŽ I 808, ZtŽ 332); strielčius ("shooter, huntsman”), cf. Polish strzelec, Belarusian стрэлеu (DrskŽ 352, DvŽ II 299, KpZ̆ III 876, KrtnŽ 394, ZanŽ III 196); rimorius (“leatherworker”), cf. Polish rymarz (DrskŽ 305, KpŽ III 499, KzRŽ II 176, ZanŽ II 557).

Dialects are affected by various linguistic and extralinguistic factors. The intensity of word loaning depends on the outer circumstances of language or dialect. Loanwords only fill gaps in some fields. The research of Slavisms provides abundant material for the study of their origins as well as how and why they spread, and of the history of Lithuanian dialects in general.

Keywords: lexis; dialect dictionary; Lithuanian dialects; loanwords; slavism

Correspondence: V. Sakalauskienè, Institute of the Lithuanian Language, e-mail: vilija.sakalauskiene@lki.lt

This work was supported by a core funding for statutory activities from Institute of the Lithuanian Language.

Competing interests: the author declares that she has no competing interests. 